\title{
Polyphenol nanoformulations for cancer therapy: experimental evidence and clinical perspective
}

\author{
This article was published in the following Dove Press journal: \\ International Journal of Nanomedicine \\ 4 April 2017 \\ Number of times this article has been viewed
}

\section{Yasamin Davatgaran- \\ Taghipour ${ }^{1,2}$ \\ Salar Masoomzadeh ${ }^{3}$ \\ Mohammad Hosein \\ Farzaei ${ }^{4,5}$ \\ Roodabeh Bahramsoltani ${ }^{6}$ \\ Zahra Karimi-Soureh ${ }^{7}$ \\ Roja Rahimi ${ }^{6,8}$ \\ Mohammad Abdollahi ${ }^{9}, 10$}

'Department of Medical Nanotechnology, School of Advanced Technologies in Medicine, Tehran University of Medical

Sciences, Tehran, Iran; ${ }^{2}$ PhytoPharmacology Interest Group (PPIG), Universal Scientific Education and Research Network (USERN), Tehran, Iran; ${ }^{3}$ Zanjan Pharmaceutical Nanotechnology Research Center, School of Pharmacy, Zanjan University of Medical Sciences, Zanjan, Iran; ${ }^{4}$ Pharmaceutical Sciences Research Center, Kermanshah University of Medical Sciences, Kermanshah, Iran; ${ }^{5}$ Medical Biology Research Center, Kermanshah University of Medical

Sciences, Kermanshah, Iran; ${ }^{6}$ Department of Traditional Pharmacy, School of Traditional Medicine, Tehran University of Medical Sciences, Tehran, Iran; ${ }^{7}$ School of Pharmacy, Shahid Beheshti University of Medical Sciences, Tehran, Iran; ${ }^{8}$ EvidenceBased Medicine Group, Pharmaceutical Sciences Research Center, Tehran University of Medical Sciences, Tehran, Iran; ${ }^{9}$ Toxicology and Diseases Group, Pharmaceutical Sciences Research Center, Tehran University of Medical Sciences, Tehran, Iran; ${ }^{10}$ Department of Toxicology and Pharmacology, Faculty of Pharmacy and Pharmaceutical Sciences Research Center, Tehran University of Medical Sciences, Tehran, Iran

Correspondence: Mohammad Abdollahi Division of Toxicology, Department of Toxicology and Pharmacology, Faculty of Pharmacy and Pharmaceutical Sciences Research Center, Tehran University of Medical Sciences, Keshavarz Bulvard, Ebn-E-Sina Street, Tehran 14176I44II, Iran

Emailmohammad@tums.ac.ir
Abstract: Cancer is defined as the abnormal cell growth that can cause life-threatening malignancies with high financial costs for patients as well as the health care system. Natural polyphenols have long been used for the prevention and treatment of several disorders due to their antioxidant, anti-inflammatory, cytotoxic, antineoplastic, and immunomodulatory effects discussed in the literature; thus, these phytochemicals are potentially able to act as chemopreventive and chemotherapeutic agents in different types of cancer. One of the problems regarding the use of polyphenolic compounds is their low bioavailability. Different types of formulations have been designed for the improvement of bioavailability of these compounds, nanonization being one of the most notable approaches among them. This study aimed to review current data on the nanoformulations of natural polyphenols as chemopreventive and chemotherapeutic agents and to discuss their molecular anticancer mechanisms of action. Nanoformulations of natural polyphenols as bioactive agents, including resveratrol, curcumin, quercetin, epigallocatechin-3-gallate, chrysin, baicalein, luteolin, honokiol, silibinin, and coumarin derivatives, in a dose-dependent manner, result in better efficacy for the prevention and treatment of cancer. The impact of nanoformulation methods for these natural agents on tumor cells has gained wider attention due to improvement in targeted therapy and bioavailability, as well as enhancement of stability. Today, several nanoformulations are designed for delivery of polyphenolic compounds, including nanosuspensions, solid lipid nanoparticles, liposomes, gold nanoparticles, and polymeric nanoparticles, which have resulted in better antineoplastic activity, higher intracellular concentration of polyphenols, slow and sustained release of the drugs, and improvement of proapoptotic activity against tumor cells. To conclude, natural polyphenols demonstrate remarkable anticancer potential in pharmacotherapy; however, the obstacles in terms of their bioavailability in and toxicity to normal cells, as well as targeted drug delivery to malignant cells, can be overcome using nanoformulation-based technologies, which optimize the bioefficacy of these natural drugs.

Keywords: natural products, flavonoid, anthocyanin, tumor, malignancy

\section{Introduction}

Cancer has always been a great health problem all over the world despite growing advances in its prevention and treatment strategies. This disease is characterized by abnormal proliferation of cells that cannot be controlled or stopped. In addition, cells of malignant tumors have a tendency to become metastatic and attack tissues other than the place in which the primary tumor was formed. ${ }^{1}$ Common modalities in the treatment of cancer consist of nonpharmacological treatments, such as radiation therapy, surgical operation, stem cell therapy and hyperthermia, as well as pharmacological intervention, including immunotherapy, chemotherapy, and hormone therapy, as well as a combination of these methods. ${ }^{1}$ Nevertheless, all of these methods, 
including chemotherapy, have significant limitations such as dissatisfying specificity, which can cause low concentrations of drugs at the tumor site, causing multiple side effects and off-target toxic effects. ${ }^{2}$

Nanotechnology is the study of particles within the range of $\leq 100 \mathrm{~nm}$, and a nanometer is defined as one-billionth of a meter. ${ }^{3}$ High surface area-to-volume ratio of atoms or molecules is one of the significant advantages of nanoparticles. This property leads to boosting of the surface activity and changes the physical and biological properties of the nanomaterials.

Rapid diagnosis of cancer and exact targeted drug delivery to the site of the neoplasms with the least possible adverse effects on other normal tissues are the desired goals of anticancer therapies. Nanotechnology has shown promising effects in the treatment of cancer. ${ }^{4}$ Through targeted drug delivery via nanoformulations, improvement in drug delivery to the tumor site can be achieved, and better therapeutic responses are expected. Another parameter is the increased selectivity that reduces the adverse effects of chemotherapy drugs. ${ }^{5}$ Nanoformulations such as liposomes, ${ }^{6}$ micelles, ${ }^{7}$ natural and synthetic nanoparticles, metal nanoparticles, and microspheres are among the important nanoformulations. Selection of these methods for nanoformulation provides improvements in bioavailability, biodistribution, specificity, and pharmacokinetics of drugs delivered to the site of tumor. Recently, several liposomal formulations have become available in the market for treatment of cancer, such as doxorubicin $\left(\right.$ Doxil $\left.^{\circledR}\right)$, cytarabine $\left(\right.$ Depocyt $\left.^{\circledR}\right)$, daunorubicin $\left(\right.$ DaunoXome $\left.{ }^{\circledR}\right)$, and vincristine $\left(\right.$ Onco-TCS $\left.{ }^{\circledR}\right)$. Doxil has been examined for head and neck cancer, brain tumors, ovarian cancer, breast neoplasms, and acquired immunodeficiency syndrome (AIDS)-related Kaposi's sarcoma. Liposomal drug delivery has shown great promise, but it still has obstacles to overcome, including its short shelf life, limited loading potential, insufficient bioavailability on oral administration, decomposition of the drug inside the liposome, lack of enough control of drug release, and the unpredictable clearance by the reticuloendothelial system (RES). Polymeric, metal-, or lipid-based nanoparticles have a fundamental advantage for systemic drug delivery due to their smaller size, which permits lower RES uptake, extended circulation time, and better ability of penetration into capillaries..$^{8,9}$

Polyphenolic compounds comprise one of the most diverse groups of plant secondary metabolites, with several health-promoting properties, including antioxidant, antiinflammatory, and antineoplastic activities. ${ }^{10}$ Previous studies have discussed the anticancer effects of numerous natural polyphenols such as curcumin, resveratrol, and several flavonoids; ${ }^{11}$ thus, these compounds have attracted the attention of scientists for more extensive research.

The aim of the current study is to review current available data on the nanoformulations of natural polyphenols as chemopreventive and chemotherapeutic agents and to discuss the molecular mechanisms of their anticancer action.

\section{Description of study selection}

Electronic databases including "Scopus", "PubMed", and "ScienceDirect" were searched with the keywords "cancer" in title/abstract, along with "plant", "phytochemical", "extract", and "herb" in the whole text. Data were collected from the inception date until August 2016. Only English language papers were included. Primarily obtained articles were screened by two independent investigators. Articles that had assessed nanoformulations of polyphenolic compounds in an in vitro or in vivo model of cancer were selected for this study, and conventional formulations (without using a nanonization technique), preparations of phytochemicals other than polyphenols, eg, terpenoids or alkaloids, and animal or cellular models of disease other than cancer were excluded. References of the retrieved studies were also screened for relevant articles. Included articles were screened for the name of phytochemical, nanonization technique, and the type of cancer in animal or cellular models. From a total of 1,939 results, 1,033 were excluded because of duplication, 138 for being reviews, and 713 being irrelevant judged on the title and/or abstract. From the 55 primarily selected papers, 15 were excluded based on the full texts (four were excluded because they were not on polyphenols, four because no anticancer effects were assessed, three because the cell cultures were not cancerous cell lines, three because the polyphenol was not prepared in the form of a nanoformulation, and 1 because the full-text was in Chinese). Finally, 40 articles were included in this review. Table 1 shows the summary of the obtained results.

\section{Nanostructures and polymers}

Several polymers and nanostructures have been used for the preparation of polyphenolic compounds as anticancer agents. Poly(lactic-co-glycolic acid) (PLGA) nanoparticles are a group of hydrophobic, biocompatible, and biodegradable polymers that have attracted immense interest since being approved by the US Food and Drug Administration as a safe drug delivery system. This polymer consists of lactic acid and glycolic acid, which can be metabolized by the body, and the degradation rate depends on their ratio. ${ }^{12}$ Polylactic acid 
Table I Polyphenols with anticancer activity and their mechanisms of action

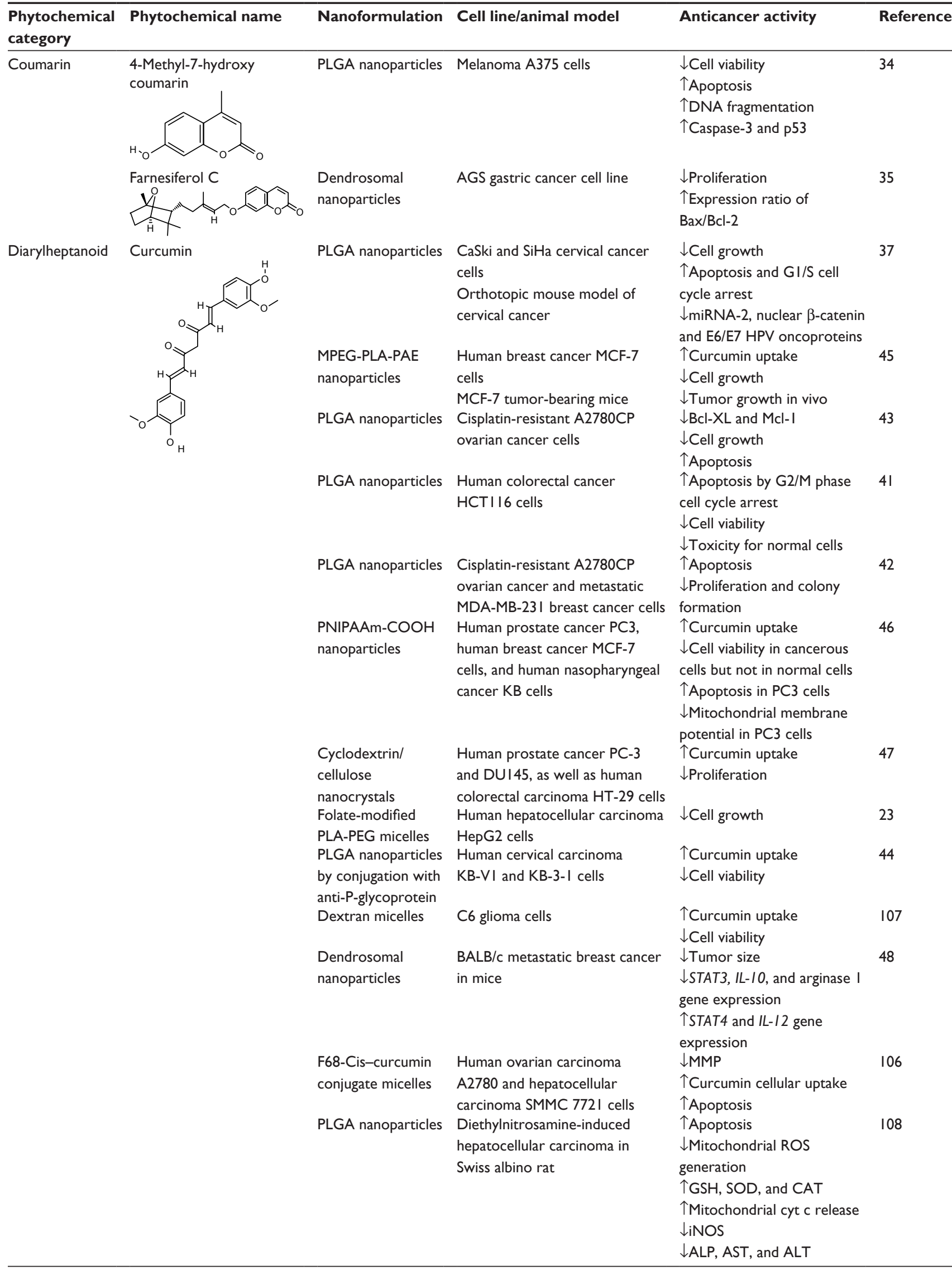


Table I (Continued)

\begin{tabular}{|c|c|c|c|c|c|}
\hline Phytochemical & Phytochemical name & Nanoformulation & Cell line/animal model & Anticancer activity & Reference \\
\hline & & PCL nanodroplets & SI 80 cancer-bearing mice & $\downarrow$ Tumor growth & 49 \\
\hline & & PHEMA & Ovarian cancer SKOV-3 cells & $\downarrow$ Tumor growth & 109 \\
\hline & & nanoparticles & & $\uparrow$ Apoptosis & \\
\hline & & Colloidal & Esophageal Barrett cancer OEI9 & $\downarrow$ Proliferation in cancerous & 110 \\
\hline & & nanoparticles & and OE33 cells & cells but not in normal cells & \\
\hline & & & & No significant effect on & \\
\hline & & & & apoptosis & \\
\hline & & & & $\downarrow$ Activated T-cell apoptosis & \\
\hline & & & & and production of TNF- $\alpha$, & \\
\hline & & & & IL-8, IL-6, IL-I0, and IL-I $\beta$ & \\
\hline & & Nanoparticles & Human embyronic kidney HEK & $\downarrow$ Cell viability (more obvious & 51 \\
\hline & & prepared by & and human PC3 prostate cancer & on HEK cells) & \\
\hline & & $\begin{array}{l}\text { ultrasonic spray } \\
\text { Nanostructured }\end{array}$ & $\begin{array}{l}\text { cells } \\
\text { Human neuroblastoma LAN5 }\end{array}$ & $\downarrow$ Cell viability & 52 \\
\hline & & $\begin{array}{l}\text { Nanostructured } \\
\text { lipid carriers }\end{array}$ & cells & $\uparrow \mathrm{Hsp} 70$ & 52 \\
\hline & & $\begin{array}{l}\text { lipid carriers } \\
\text { Polymer-coated }\end{array}$ & Human ovarian carcinoma & $\downarrow$ Cell viability & \\
\hline & & magnetic & SKOV-3 cells & Wentidabiticy & 33 \\
\hline & & nanoparticles & & & \\
\hline & & Lipid-polymer & Human PC3 prostate & $\uparrow$ Adherence ability of & 54 \\
\hline & & hybrid & adenocarcinoma cells, BALB/c & the nanocarriers to cell & \\
\hline & & nanoparticles in & nude mice & membrane in $\mathrm{PC} 3$ & \\
\hline & & combination with & & $\uparrow$ Antitumor effects in PC3 & \\
\hline & & docetaxel & & $\downarrow$ Tumor growth in vivo & \\
\hline \multirow[t]{30}{*}{ Flavonoid } & Baical & Paclitaxel-baicalein & Human lung cancer A549 & $\downarrow$ Cell viability & 82 \\
\hline & & dual-targeted & and drug-resistant lung cancer & $\downarrow$ Tumor growth in vivo & \\
\hline & & ligands of folate and & A549/PTX cells, xenograft & & \\
\hline & & hyaluronic acid & mouse model of A549/PTX & & \\
\hline & & & drug-resistant human lung cancer & & \\
\hline & $\mathrm{Ch}$ & Nanosuspension & Human hepatocellular carcinoma & $\downarrow$ Cell growth & 85 \\
\hline & & & HepG2 cells & & \\
\hline & EGCG & $\mathrm{Ca} / \mathrm{AlNO}_{3}$-layered & Human prostate cancer PC-3 & $\uparrow$ Apoptosis & 87 \\
\hline & & double-hydroxide & cells & $\downarrow$ Cell viability & \\
\hline & & nanoparticles & & $\downarrow$ Colony formation & \\
\hline & & Chitosan & Human melanoma Mel 928 cells, & $\uparrow$ Apoptosis & 88 \\
\hline & & nanoparticles & xenograft athymic nu/nu mouse & $\downarrow$ Cell viability & \\
\hline & & & model of melanoma & $\uparrow \mathrm{Bax}$ & \\
\hline & & & & $\downarrow \mathrm{BCl}-2$ & \\
\hline & & & & $\downarrow$ Caspase- 3 and caspase-9 & \\
\hline & & & & protein expression & \\
\hline & & & & $\uparrow$ Cleaved caspase- 9 & \\
\hline & & & & TPARP cleavage & \\
\hline & & & & G2/M phase cell cycle arrest & \\
\hline & & & & Induction of $\mathrm{p} 21$ and $\mathrm{p} 27$ & \\
\hline & & & & Inhibition of cyclin & \\
\hline & & & & $\mathrm{DI}$ and $\mathrm{D} 3$ & \\
\hline & & & & $\downarrow$ Tumor growth and & \\
\hline & & & & proliferation in vivo & \\
\hline & & & & Inhibition of CDK 4 and 6 & \\
\hline & & & & $\uparrow$ Apoptosis & \\
\hline & EGCG (+ paclitaxel) & Core-shell PLGA- & Human breast cancer MDA- & $\uparrow$ Apoptosis & 89 \\
\hline & & casein nanoparticles & MB-23I and MCF-7 cells, breast & $\downarrow N F-\kappa B$ activation & \\
\hline & & in targeted and & cancer cells isolated from & Anticancer effects on & \\
\hline & & nontargeted form & patients & patients samples & \\
\hline
\end{tabular}


Table I (Continued)

\begin{tabular}{|c|c|c|c|c|c|}
\hline Phytochemical & Phytochemical name & Nanoformulation & Cell line/animal model & Anticancer activity & Reference \\
\hline & Green tea polyphenols & $\begin{array}{l}\text { Graphene } \\
\text { nanosheets }\end{array}$ & $\begin{array}{l}\text { Colon cancer HT29 and } \\
\text { SW48 cells }\end{array}$ & $\begin{array}{l}\text { PPhotothermal destruction } \\
\text { of SW48 }\end{array}$ & 90 \\
\hline & Luteolin & Phytosome & $\begin{array}{l}\text { Human MDA-MB-23I breast } \\
\text { cancer cells }\end{array}$ & $\begin{array}{l}\downarrow \text { Cell viability } \\
\downarrow N r f 2 \text { and related downstream } \\
\text { genes Hol and MDRI } \\
\uparrow \text { Sensitivity to doxorubicin }\end{array}$ & 92 \\
\hline & & $\begin{array}{l}\text { PLA-PEG-OMe } \\
\text { nanoparticles }\end{array}$ & $\begin{array}{l}\text { Lung cancer H292 cells, } \\
\text { squamous cell carcinoma of } \\
\text { head-and-neck Tu2 } 212 \text { cells, } \\
\text { xenograft mouse model of head } \\
\text { and neck cancer }\end{array}$ & $\begin{array}{l}\downarrow \text { Tumor growth } \\
\downarrow \text { Colony formation } \\
\downarrow \text { Tumor size in animals }\end{array}$ & 93 \\
\hline & Quer & Phytosome & $\begin{array}{l}\text { Human breast cancer } \\
\text { MCF-7 cells }\end{array}$ & $\begin{array}{l}\uparrow \text { Apoptosis } \\
\text { No significant change in Nrf2 } \\
\downarrow_{\text {mRNA expression of Nrf2 }} \\
\text { downstream genes NQOI } \\
\text { and MRPI }\end{array}$ & 95 \\
\hline & & Liposome & $\begin{array}{l}\text { Human breast cancer } \\
\text { MCF-7 cells }\end{array}$ & $\begin{array}{l}\downarrow \text { Cell proliferation } \\
\uparrow \text { Antitoxic effect }\end{array}$ & 96 \\
\hline Flavonolignan & yrrhizic acid) & $\begin{array}{l}\text { Pegylated } \\
\text { nanoliposomes }\end{array}$ & $\begin{array}{l}\text { Human hepatocellular carcinoma } \\
\text { HepG } 2 \text { cells }\end{array}$ & $\begin{array}{l}\downarrow \text { Cell viability in cancerous } \\
\text { cells but not in normal cells }\end{array}$ & 55 \\
\hline Lignan & Hon & MPEG micelles & $\begin{array}{l}\text { Mouse Lewis lung cancer cell } \\
\text { lines LL/2 }\end{array}$ & $\begin{array}{l}\downarrow \text { Cell growth } \\
\text { Induction of cell cycle arrest } \\
\text { in G0/GI phase }\end{array}$ & 60 \\
\hline Naphthoquinone & Plur & Silver nanoparticles & $\begin{array}{l}\text { Human skin } \mathrm{HaCaT} \text { and } \\
\text { A43I cells }\end{array}$ & $\begin{array}{l}\uparrow \text { Pyruvate kinase activity } \\
\text { (more obvious in A43I) } \\
\uparrow \text { Apoptosis by production of } \\
\text { free radicals }\end{array}$ & 66 \\
\hline \multirow[t]{5}{*}{ Stilbene } & Resve & $\begin{array}{l}\text { PLGA-PEG-COOH } \\
\text { nanoparticles }\end{array}$ & $\begin{array}{l}\text { Human prostate cancer DU-I45, } \\
\text { PC-3, and LNCaP cells }\end{array}$ & $\begin{array}{l}\downarrow \text { Cell growth and } \\
\text { proliferation }\end{array}$ & 68 \\
\hline & & PCL nanocapsules & Murine melanoma BI6FI0 cells & $\downarrow$ Tumor growth & 69 \\
\hline & & $\begin{array}{l}\text { MPEG-PCL } \\
\text { nanoparticles }\end{array}$ & Rat C6 glioma cells & $\downarrow$ Cell viability & 70 \\
\hline & & $\begin{array}{l}\text { Pegylated } \\
\text { coencapsulation } \\
\text { with 5-FU }\end{array}$ & $\begin{array}{l}\text { Human NT8e head and neck } \\
\text { cancer }\end{array}$ & $\begin{array}{l}\text { Synergistic antineoplastic } \\
\text { effect at high concentrations } \\
\text { and antagonistic effect at low } \\
\text { concentrations of resveratrol } \\
\uparrow \mathrm{Bax} \\
\downarrow \mathrm{Bcl}-2\end{array}$ & 72 \\
\hline & & $\begin{array}{l}\text { Bovine serum } \\
\text { albumin } \\
\text { Nanoparticles }\end{array}$ & $\begin{array}{l}\text { Human ovarian cancer } \\
\text { SKOV } 3 \text { cells }\end{array}$ & $\begin{array}{l}\uparrow \text { Apoptosis } \\
\uparrow \text { Bax } \\
\text { } D \text { DA fragmentation } \\
\uparrow \text { Cyt } c \text { and apoptosis- } \\
\text { inducing factor release }\end{array}$ & 71 \\
\hline
\end{tabular}

Abbreviations: ALP, alkaline phosphatase; AST, aspartate aminotransferase; ALT, alanine aminotransferase; CAT, catalase; cyt c, cytochrome c; 5-FU, 5-fluorouracil; GSH, glutathione; HPV, human papillomavirus; IL, interleukin; iNOS, inducible nitric oxide synthase; miRNA, microRNA; MMP, mitochondrial membrane potential; MPEG, methoxy polyethylene glycol; MPEG-PLA-PAE, (MPEG)-poly(lactide)-poly(b-amino ester); OMe, methoxy group; PAE, poly(b-amino ester); PARP, poly(ADP-ribose) polymerase; PCL, poly(ع-caprolactone); PEG, polyethylene glycol; pegylated, conjugated with PEG; PHEMA, poly(2-hydroxyethyl methacrylate); PLA, polylactic acid; PLGA, poly(lactic-coglycolic acid); PNIPAAm, poly(N-isopropylacrylamide); ROS, reactive oxygen species; SOD, superoxide dismutase; TNF, tumor necrosis factor. 
(PLA) is another biodegradable and biocompatible polymer that is metabolized into monomeric units of lactic acid in the body. The preparation method for PLA nanoparticles is mostly via solvent evaporation, solvent displacement, ${ }^{13}$ salting out, ${ }^{14}$ and solvent diffusion. ${ }^{15}$ Recently, researchers have focused on polymeric systems activated by a watersoluble stimulus, which represents a phase transition in response to external stimuli such as $\mathrm{pH}$, specific ions, temperature, and electrical field.

Dendrosome is an amphipathic, neutral, and biodegradable nanostructure that has been used for delivering genes into diverse cell lines. ${ }^{16}$ Dendrosomes are liposomes encapsulating dendrimers in their aqueous core and can be functionalized using different functional groups. ${ }^{17}$

Poly( $\beta$-amino ester) (PAE) is a biodegradable and $\mathrm{pH}-$ responsive polymer that is not soluble at $\mathrm{pH}$ of 7.4, but it turns into a soluble form at a lower $\mathrm{pH}(<6.8)$ through the protonation process of tertiary amino groups. ${ }^{18}$ Another popular polymer is $\operatorname{poly}(N$-isopropylacrylamide) (PNIPAAm) that is used for the preparation of temperature- and $\mathrm{pH}$-sensitive structures for biomedical applications. ${ }^{19}$ Cyclodextrins (CDs) consist of cyclic oligosaccharide molecular structures including six (a-), seven (b-), or eight (c-) D-glucopyranose units linked together by $\alpha-(1,4)$ glycosidic linkages. These structures are popular to form molecular complexes loaded with other molecules, eg, drugs. ${ }^{20} \beta-\mathrm{CD}$ is the most commonly used type because of the easier synthesis, low price, and large loading capacity for polar molecules that can be loaded into the internal cavity.

A new drug delivery system for anticancer drugs is based on cellulose nanocrystals (CNCs) consisting of uniform nanorods with liquid crystalline features, high mechanical resistance, high surface area-to-volume ratio, ability for sustained drug release, biodegradability, and biocompatibility. ${ }^{21}$ This structure is obtained by the acid hydrolysis of cotton fibers, and the surface can be easily modified. ${ }^{22}$

Micelles are lipid structures that are converted into a spherical form in water. This reaction is the result of the amphipathic properties of fatty acid molecules, which contain both hydrophilic polar heads and long hydrophobic regions. The hydrophilic head groups of micelles usually form the outside surface of micelles, and the hydrophobic tails are retained inside because they are nonpolar. The core-shell structure of the polymeric micelles is the result of the amphiphilic block, which is useful for solubilizing water-insoluble or poorly soluble drugs. Some advantages of the use of micelles as a drug delivery system include conjugation with the targeted molecules via surface modification, trapping of hydrophobic drugs into a hydrophobic core that protects drugs from fast degradation, and reduction of nonspecific uptake by RES. ${ }^{23}$

Poly( $\varepsilon$-caprolactone) (PCL) is a biodegradable and biocompatible polymer that is extensively studied for controlled drug delivery systems. ${ }^{24} \mathrm{~A}$ wide range of drugs are compatible with this polymer, which provides homogeneous drug dispersal in the formulation and lower degradation rate. ${ }^{24}$ Poly(2-hydroxyethyl methacrylate) (PHEMA) is an artificially synthesized polymer with numerous applications in medical instruments and devices, such as soft contact lenses and artificial cornea, as well as in drug delivery systems. ${ }^{25}$ The polar hydroxyl groups and carbonyl functional groups on the repeating units of PHEMA make it a water-compatible polymer. Hydrophobic $\alpha$-methyl groups in the PHEMA backbone result in better hydrolytic stability of the polymer. ${ }^{26}$ Among the different drug delivery systems, lipid nanoparticles, such as nanostructured lipid carriers, can be applied for the delivery of many types of drugs. ${ }^{27}$ Large-scale production in high quality and lack of need for organic solvent during the production are advantages of lipid-based nanocarriers. They have good stability during long storage and can be either lyophilized or steam sterilized. ${ }^{28}$ Nanostructured lipid carriers consist of standard ingredients for pharmaceutical use in humans and are recognized as safe structures. ${ }^{29}$

\section{Polyphenol nanoformulations for cancer therapy Coumarins}

Coumarins are polyphenols with appetite-suppressing properties that discourage animals from eating plants containing them. They can also be used in the treatment of lymphedema. ${ }^{30}$ They can also cause bleeding, which is their most well-known feature. ${ }^{31}$ Fabaceae, Lamiaceae, ${ }^{32}$ and Rosaceae $\mathrm{e}^{33}$ are among the natural sources of coumarins. These phytochemicals have shown anticancer properties via several mechanisms of action.

4-Methyl-7-hydroxycoumarin is a synthetic coumarin that is made by methylation of umbelliferone (7-hydroxycoumarin). PLGA nanoparticles of 4-methyl-7-hydroxy coumarin have demonstrated anticancer effects in melanoma A375 cell cultures by increasing cell apoptosis, DNA fragmentation, caspase-3, and p53 (tumor suppressor factors) and by decreasing cell viability. ${ }^{34}$ Farnesiferol $\mathrm{C}$ is another coumarin extracted from plant species such as Ferula asafoetida. Dendrosomal nanoformulation of farnesiferol $\mathrm{C}$ exhibited antineoplastic activity by decreasing cell proliferation in AGS gastric cancer cell line. The expression of Bax (an antiapoptotic marker) and Bcl-2 (a proapoptotic factor) was 
modified so that the $\mathrm{Bax} / \mathrm{Bcl}-2$ ratio increased as a result of treatment with dendrosomal farnesiferol C. ${ }^{35}$

\section{Diarylheptanoid (curcumin)}

Curcumin is the principal diarylheptanoid polyphenolic structure extracted from turmeric (Curcuma longa) rhizome, and it has numerous biological and pharmacological properties such as antioxidant, anti-inflammatory, and anticarcinogenic activities. It has been thoroughly studied in the field of cancer therapeutics. ${ }^{36}$

Several studies have assessed the antineoplastic properties of curcumin-loaded PLGA nanoparticles on different cancerous cell lines. The anticancer activity of nanocurcumin in cervical cancer has been investigated, wherein CaSki and $\mathrm{SiHa}$ cells were treated with nanocurcumin, which resulted in reduction of cell growth and cellular proliferation. The formulation also induced apoptosis via G1/S cell cycle arrest. ${ }^{37}$ Beta-catenin is a protein involved in transcription and cell proliferation, whose phosphorylation is controlled by glycogen synthase kinase 3 (GSK3); thus, any malfunction in $\beta$-catenin signaling can result in abnormal cell proliferation. ${ }^{38}$ Small noncoding sequences of RNA, known as microRNAs (miRNAs), are found to have regulatory effects on oncogenic or tumor suppressor genes and to be involved in tumorigenesis. Investigations have suggested miRNAs as novel therapeutic targets for cancer. The potential therapies of miRNAs with oncogenic activities include miRNA masking, microRNA sponges, and anti-miRNA oligonucleotides. Natural agents that block or enhance the expression of specific miRNAs can lead to the suppression of oncogenic effects..$^{39,40}$ Nanocurcumin has been shown to diminish the levels of miRNA-2, nuclear $\beta$-catenin, and E6/E7 human papillomavirus (HPV) oncoproteins in an orthotopic mouse model of cervical cancer. ${ }^{37}$ Using the same formulation, Xie et $\mathrm{al}^{41}$ showed the anticancer effects in human colorectal cancer HCT116 cells via decrease in cell viability, increase in apoptosis by $\mathrm{G} 2 / \mathrm{M}$ phase cell cycle arrest, and decrease in the toxicity for normal cells. In another study, PLGA nanocurcumin showed antineoplastic properties for cisplatin-resistant $\mathrm{A} 2780 \mathrm{CP}$ ovarian cancer cells, as well as metastatic MDA-MB-231 breast cancer cell cultures by increasing apoptosis and decreasing tumor cell proliferation and colony formation..$^{42}$ The same formulation could elevate mitochondrial cytochrome (cyt) $\mathrm{C}$ release and reduce both mitochondrial reactive oxygen species (ROS) generation as well as levels of inducible nitric oxide synthase (iNOS), alkaline phosphatase (ALP), aspartate aminotransferase (AST), and alanine aminotransferase
(ALT), in diethylnitrosamine-induced hepatocellular carcinoma in Swiss albino rat. ${ }^{43}$

PLGA nanoparticles loaded with curcumin and conjugated with anti-P-glycoprotein could exhibit cytotoxic effects in human cervical carcinoma KB-V1 and KB-3-1 cells, which resulted in increased curcumin solubility and cellular uptake as well as decreased cell viability. ${ }^{44} \mathrm{~A}$ micellar system based on methoxy polyethylene glycol (MPEG)-poly(lactide)poly(b-amino ester) (MPEG-PLA-PAE) copolymers loaded with curcumin was assessed for its anticancer activity in MCF-7 human breast cancer cell cultures and MCF-7 tumorbearing mice. The study showed better cellular internalization than free curcumin and significantly diminished tumor cell growth both in vitro and in vivo. ${ }^{45} \mathrm{~A}$ nanoformulation of thermoresponsive chitosan-g-poly( $N$-isopropylacrylamide) co-polymeric nanoparticles (TRC-NPs) loaded with curcumin was tested for anticancer effects in human prostate cancer PC3, breast cancer MCF-7 cells, and human nasopharyngeal cancer KB cells. ${ }^{46}$ The formulation yielded a better uptake of curcumin by cancerous cells, decreased the cell viability, and augmented apoptosis in PC3 cells, as well as diminished the mitochondrial membrane potential in PC 3 cells. ${ }^{46}$ In a recent study, ${ }^{47} \mathrm{CD} / \mathrm{CNCs}$ loaded with curcumin were examined. The formulation improved the cellular uptake of curcumin and could inhibit cell proliferation in human prostate cancer PC-3 and DU145 cells and in human colorectal carcinoma HT-29 cells. ${ }^{47}$ In another study, folate-modified PLA-PEG micelles loaded with curcumin were examined in human hepatocellular carcinoma HepG2 cells, which resulted in decreased cell growth. ${ }^{23}$ Dextran micelles loaded with curcumin were studied as a $\mathrm{pH}$-sensitive drug delivery system in C6 glioma cells, which demonstrated improved cellular uptake and reduction of cell proliferation..$^{23}$ Dendrosomal nanoparticles loaded with curcumin exhibited antineoplastic activity in metastatic breast cancer cells in BALB/c mice by reducing the tumor size and expression of the STAT3, interleukin-10 (IL-10), and arginase-1 genes, as well as by augmentation of STAT4 and $I L-12$ gene expression. ${ }^{48}$ Curcumin-loaded caprolactone was also found to decrease tumor growth in S180 cancer-bearing mice. ${ }^{49}$ Curcuminloaded PHEMA nanoparticles could increase apoptosis and inhibit tumor cell growth in ovarian cancer SKOV-3 cells. ${ }^{49}$ The colloidal system of curcumin nanoparticles in esophageal Barrett cancer OE19 and OE33 cells was tested. ${ }^{50}$ The results showed a decrease in proliferation rate of cancer cells, but not in normal cells. The formulation also activated apoptosis of T cells and reduced the production of IL-1 $1 \beta$, IL-6, IL-8, IL-10, and tumor necrosis factor (TNF)- $\alpha .{ }^{50}$ Nanoparticles 
of curcumin prepared by ultrasonic spray also showed anticancer properties in human PC3 prostate cancer and human embyronic kidney HEK cell lines. ${ }^{51}$ Nanostructured lipid carriers loaded with curcumin were examined in human neuroblastoma LAN5 cells, which showed diminishing cell viability and increasing Hsp70 activity. ${ }^{52}$ Polymer-coated magnetic nanoparticles of curcumin could decrease cell viability in human ovarian carcinoma SKOV-3 cells.$^{53}$ Lipidpolymer hybrid nanoparticles loaded with a combination of docetaxel and curcumin were studied in human PC3 prostate adenocarcinoma cells, which resulted in better adherence of the nanoparticles to the cell membrane and antitumor effects in PC3 cells. ${ }^{54}$ In vivo tumor growth was also inhibited by a docetaxel-curcumin nanoformulation in a BALB/c nude mouse model of the disease. ${ }^{54}$

\section{Flavonolignans}

Flavonolignans are natural compounds of flavonoids and lignans with antioxidant and hepatoprotective properties. Silibinin, silychristin, silydianin, dehydrosilybin, and deoxysilycistin are the examples of flavonolignans that can be found in sylimarin, the extract of milk thistle (Sylibum marianum), and in other plants of the Asteraceae family. ${ }^{55}$

Silibinin in combination with glycyrrhizic acid (a triterpene from licorice), formulated as nanoliposomes containing its PEG conjugate (pegylated nanoliposomes), demonstrated its anticancer effect by decreasing the cell viability in human hepatocellular carcinoma HepG 2 cells. The nanoformulation was about 10 -fold more potent than the free molecules. ${ }^{55}$

\section{Lignans}

Lignans are plant chemical compounds that are found in dietary fiber; thus, fiber-rich food items can be a good source for lignans. Plants of Pedaliaceae ${ }^{56}$ and Linaceae ${ }^{57}$ families are among the well-known sources of lignans. Lignans have several therapeutic activities such as anti-inflammatory and antioxidant properties, which are beneficial for the management of pathologic conditions in humans. ${ }^{58}$

Honokiol is a lignan extracted from the seed cones, bark, and leaves of trees of the Magnoliaceae family. ${ }^{59}$ A nanoformulation of honokiol caused an anticancer effect in the mouse Lewis lung cancer LL/2 cell lines by induction of cell cycle arrest at the $\mathrm{G} 0 / \mathrm{G} 1$ phase. $^{60}$

\section{Naphthoquinones}

Naphthoquinones are a subcategory of phenolic compounds derived from naphthalene. Alkanin from Alkanna tinctoria ${ }^{61}$ and juglone from Juglans regia ${ }^{62}$ are well-known examples of naphthoquinones. Naphthoquinones have an important role in blood coagulation and ossification. Overuse of naphthoquinones can cause internal bleeding and peptic ulcers. ${ }^{63}$ Naphthoquinones have also demonstrated acceptable anticancer properties and have attracted the attention of scientists to be formulated as a novel drug delivery system such as nanoparticles.

Plumbagin is a naphthoquinone that is extracted from Plumbago spp, family Plumbaginaceae, and it has demonstrated anticancer activity in human cancerous cell lines. ${ }^{64}$ Silver nanoparticles of plumbagin induced apoptosis in cancerous human skin $\mathrm{HaCaT}$ and A431 cells by producing free radicals. The compound also showed anticancer effect by increasing pyruvate kinase activity (an enzyme that catalyzes pyruvate and ATP synthesis in glycolysis and has a crucial role in the metabolism of normal as well as cancerous cells). ${ }^{65,66}$

\section{Stilbenes}

Stilbenes are E- or Z-isomers of 1,2-diphenylethene derivatives. These compounds are distributed in a few number of plant families, especially Vitaceae (grapes family), which is the source of the most well-known stilbene, resveratrol. ${ }^{67}$ There are numerous studies on the anticancer properties of resveratrol. Nanoformulated resveratrol using PLGAPEG demonstrated anticancer effects by decreasing cell growth and proliferation in human prostate cancer DU-145, PC-3, and LNCaP cell lines. ${ }^{68}$ Another study also reported the antineoplastic activity of resveratrol PCL nanocapsule formulation on cultures of mouse B16F10 skin melanoma cells. ${ }^{69}$ In rat C6 glioma cells, resveratrol nanoformulated with MPEG-PCL polymer exhibited cytotoxic effects. ${ }^{70}$ Bovine serum albumin nanoparticles of resveratrol also inhibited tumor growth in a nude mouse model of human ovarian cancer SKOV3 cells. ${ }^{71}$ Resveratrol coencapsulated with 5-fluorouracil (5-FU) using PEG polymer showed mixed cytotoxicity in human NT8e head and neck cancer, because the effect was synergistic at high concentrations of resveratrol, whereas an antagonistic effect was observed with low resveratrol concentrations. ${ }^{72}$ This shows that the use of resveratrol in cancer should be closely monitored; otherwise, it may cause undesirable results.

\section{Flavonoids}

Flavonoids are a group of polyphenols that have several subclasses, such as chalcones, flavones, isoflavones, flavanones, flavonols, and anthocyanins. ${ }^{73}$ Many pharmacological effects of flavonoids have been reported, such as antioxidant, ${ }^{74}$ 
anti-inflammatory, ${ }^{75}$ immunomodulatory ${ }^{76}$ and antineoplastic activities. ${ }^{77}$ Flavonoids can be extracted from higher plants. They can be found in yellow, orange, or red colors and are widely available as colorful fruits and vegetables in the human diet: Apiaceae (parsley), Ericaceae (blueberries), ${ }^{78}$ Rutaceae (citrus fruits), Rosaceae (apple), as well as the popular delicious product of Theobroma cacao, namely, dark chocolate. ${ }^{79}$ Flavonoids have demonstrated antineoplastic activity in several studies. ${ }^{80}$

Baicalein is a flavonoid that can be found in the roots of Scutellaria baicalensis and S. lateriflora.$^{81}$ Baicalein nanoparticles with dual-targeted ligands of folate and hyaluronic acid demonstrated anticancer effect on human lung cancer A549 as well as paclitaxel-resistant lung cancer A549/PTX cells by decreasing cell viability and inhibiting tumor growth in xenograft mouse model of A549/PTX.${ }^{82}$ Chrysin is another flavonoid that can be extracted from many plants such as Passiflora spp., as well as from some mushrooms such as Pleurotus ostreatus. ${ }^{83}$ Chrysin has many pharmacological effects such as anti-inflammatory, antioxidant, and anticancer properties. ${ }^{84}$ A nanosuspension of chrysin showed anticancer effects on human hepatocellular carcinoma HepG2 cells by inhibiting cell growth. ${ }^{85}$ EGCG can be found in several plants, especially in green tea. ${ }^{86}$ The flavonoid demonstrated anticancer effects on human and animal cells by several different mechanisms. EGCG formulated as $\mathrm{Ca} / \mathrm{Al}-\mathrm{NO}_{3}$ layered double-hydroxide nanoparticles induced apoptosis, decreased cell viability, and inhibited colony formation in human prostate cancer PC-3 cells. ${ }^{87}$ Another study reported that chitosan nanoparticles of EGCG exhibited anticancer effects on human melanoma Mel 928 cells by apoptosis via increase in Bax levels, increased poly (ADP-ribose) polymerase (PARP) cleavage, G2/M phase cell cycle arrest, inhibition of cyclin D1 and D3, induction of p21 and p27, decrease in Bcl-2, caspase-3 and caspase-9 protein expression, which resulted in the reduction of cancer cell viability. ${ }^{88}$ The anticancer effect of EGCG chitosan nanoparticles on xenograft athymic mouse model of melanoma was shown by suppression of tumor growth and proliferation, inhibition of CDK4 and 6, and an increase in apoptosis. ${ }^{88}$ EGCG core-shell PLGA-casein nanoparticles in combination with paclitaxel also showed anticancer activity on MCF-7 cells and human MDA-MB-231 breast cancer cells by increasing apoptosis and decreasing NF- $\kappa \mathrm{B}$ activation. ${ }^{89}$ Green tea polyphenols containing EGCG as one of the major components were nanoformulated by graphene nanosheets and showed anticancer effects on colon cancer HT29 and SW48 cells, via photothermal destruction of cells, assessed by high-efficiency near-infrared photothermal therapy. ${ }^{90}$ Luteolin is a flavonoid with yellow crystalline appearance and is widely found in plants and vegetables of human diet. ${ }^{91}$ Phytosomes containing luteolin demonstrated anticancer effects on human MDA-MB-231 breast cancer cells by reducing cell viability and decreasing the expression of $\mathrm{Nrf} 2$ and its related downstream gene Hol. ${ }^{92}$ The formulation also reduced sensitivity of cells to the chemotherapeutic agent doxorubicin. ${ }^{92}$ Another study ${ }^{93}$ reported that nanoformulated luteolin with PLA-PEG polymer possesses anticancer effects against lung cancer H292 cells and TU212 head and neck squamous cell carcinoma, demonstrated by inhibition of tumor growth and colony formation. In addition, these effects were observable in xenograft mouse model of head and neck cancer, which resulted in reduced tumor growth and tumor size. ${ }^{93}$ Quercetin is another widely distributed flavonoid that can be found in several fruits such as the apple. Quercetin supplements are used for their cancer-preventive effects. ${ }^{94}$ Quercetin nanoformulated as phytosomes had anticancer effects on human breast cancer MCF-7 cells by increasing apoptosis and decreasing mRNA expression of $N r f 2$ downstream genes NQO1 and MRP1; however, quercetin did not make a significant change in $\mathrm{Nrf2} .{ }^{95}$ In another study, quercetin nanoformulated in liposomes showed anticancer effects on human breast cancer MCF-7 cells by reducing cancer cell proliferation and induction of antitoxic effects. ${ }^{96}$

\section{Concerns regarding the safety of nanopolyphenols}

Although most of the current evidence supports the idea of anticancer activity of natural polyphenols, ${ }^{97}$ there are some concerns regarding their antioxidant properties, which may not only help normal cells but also increase the surveillance of cancerous cells against oxidative stress caused by conventional anticancer agents. In other words, polyphenols should act in an intelligent manner in order to support the viability of only normal cells, not the cancerous ones, which is not currently guaranteed with respect to available evidence. ${ }^{98}$

Another concern is with reference to the safety of the nanostructures used for formulation of polyphenols. As nanotechnology is rather a new field of science and research, many questions are still left unanswered. Some types of nanostructures can accumulate at the site of injection and may not be completely cleared from the blood circulation. ${ }^{99}$ It should be mentioned that nanoformulations of a drug have different physicochemical properties in comparison to their simple preparations; thus, different pharmacokinetics and pharmacodynamics are expected. Hence, studies performed 
on the simple form of the drugs cannot totally reflect the toxicity of the nanoformulated products, and toxicological studies should be conducted for nanoformulations. ${ }^{100,101}$

\section{Discussion}

Cancer has always been a major calamity for health care providers all over the world due to difficulties in the selection of a suitable treatment approach. Chemotherapy, radiotherapy, immunotherapy, and surgery are currently used in cancerous patients; nevertheless, fast cellular and molecular changes in the cells, which result in drug-resistant types of the disease, can prevent achieving the ideal results. ${ }^{102}$

Severe adverse effects of chemotherapy such as gastrointestinal complications, alopecia, bone marrow suppression, and secondary malignancies have limited its use. Lower cellular permeability, unusual vascularization, and abnormal expression of surface molecules (such as drug-resistant pumps) have caused chemotherapeutic drugs to have a low concentration in these cells. ${ }^{11}$ Nanonization, as a recently developed technique in drug delivery systems, can improve the bioavailability of antineoplastic agents via passive or active targeting. ${ }^{103}$ Table 2 shows a summary of the advantages and disadvantages of nanoformulations in comparison to conventional drugs. In the current paper, we have discussed the nanoformulation of polyphenols and their application as anticancer agents. Figure 1 summarizes the main anticancer properties of nanoformulated polyphenols.

Polyphenols, as a group of phytochemicals with a wide range of pharmacological and therapeutic activities, have been extensively studied in the area of oncology. Nanoformulations of polyphenols have been prepared using a wide variety of techniques that use carriers such as liposomes, dendrosomes, nanocapsules, and nanosheets. In addition, micelles of polymers such as PLA, PLGA, PEG, PHEMA, CD, dextran, and chitosan, as well as bovine serum albumin and silver nanoparticles, have been used. These polymers were activated by using different functional groups such as carboxyl $(\mathrm{COOH})$ or methoxy (OMe) groups. Most of these nanostructures were successful in demonstrating anticancer activity. Curcumin, resveratrol, EGCG, chrysin, baicalein, luteolin, quercetin, honokiol, silibinin, and coumarin derivatives are among the polyphenols assessed for their anticancer properties in nanoformulated forms (Table 1).

Polyphenol nanoformulations perform their anticancer activity via several cellular mechanisms, including induction of cell cycle arrest at different phases of cancer cell cycle, activation of caspase enzymes, reduction of tumor vascularization, reducing tumor cell invasion and metastasis, induction of mitochondrial damage, as well as apoptosis in the neoplasm. Apoptosis, an important indicator for anticancer therapy, is one of the main functions of nanoformulated polyphenols in cancer cells. Many natural products exert their anticancer effect through apoptosis, which is the programmed cell death responsible for removal of unwanted cells. Among the Bcl-2 family proteins that regulate apoptosis, $\mathrm{Bcl}-2$ and Bax possess opposite actions in the apoptosis process. Bcl-2 blocks apoptosis, while Bax promotes apoptosis. ${ }^{104,105}$ The elevation of the ratio of $\mathrm{Bax} / \mathrm{Bcl}-2$ has a pivotal contribution to apoptosis, which is considered as one of the main mechanisms of these drugs in the induction of apoptosis in cancer cells.

Natural remedies have been broadly administered as complementary and alternative medicines for thousands of years for the management of different types of malignancies to achieve optimal body performance. The conventional medicines delivered via currently available dosage forms provide anticancer potential only up to a suboptimal degree. Hence, the existence of limitations in the management of malignancies is predictable. This requires exploring novel drug delivery strategies for the development of targeted and safe drug delivery medicines with enhanced therapeutic activity. The most important improvement in nanoformulated polyphenols, in comparison to their free molecules, is their higher antineoplastic activity and better bioavailability, which can improve passive targeting of cancerous cells. In the meantime, this scenario requires lower doses of drugs to obtain optimum response while bypassing the pharmacokinetic problems of conventional formulations. Several studies have suggested that phytochemicals, including polyphenols, have

Table 2 Advantages and disadvantages of conventional formulations versus nanoformulations

\begin{tabular}{|c|c|c|c|}
\hline \multicolumn{2}{|l|}{ Nanoformulations } & \multicolumn{2}{|l|}{ Conventional formulations } \\
\hline Advantages & Disadvantages & Advantages & Disadvantages \\
\hline $\begin{array}{l}\text { Higher surface } \\
\text { area-to-volume ratio }\end{array}$ & $\begin{array}{l}\text { Short shelf life } \\
\text { Unpredictable toxicity, } \\
\text { stability, and pharmacokinetics }\end{array}$ & $\begin{array}{l}\text { Specified safety profile, } \\
\text { predictable toxicity, stability, } \\
\text { and pharmacokinetics }\end{array}$ & $\begin{array}{l}\text { Untargeted drug delivery } \\
\text { Uncontrollable release }\end{array}$ \\
\hline Improved bioavailability & More expensive & Less expensive & Undesirable \\
\hline Targeted drug delivery & & & pharmacokinetics \\
\hline Sustained drug release & & & \\
\hline
\end{tabular}




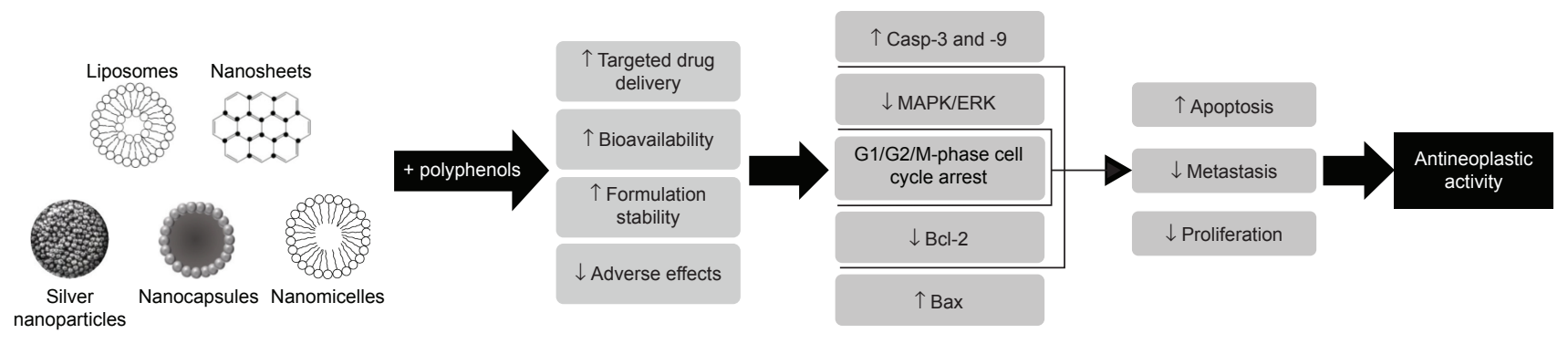

Figure I Polyphenol nanoformulations and their mechanisms as antineoplastic agents.

Abbreviations: Casp-3 and -9, caspase-3 and caspase-9; MAPK/ERK, mitogen-activated protein kinases/extracellular signal-regulated kinases.

anticancer properties exploitable in an intelligent manner, ie, showing cytotoxicity only against neoplasms, not against normal cells, whereas no such intelligence has been detected for conventional anticancer agents. ${ }^{43,52,106}$

\section{Conclusion}

Thus, polyphenols are suitable candidates to be studied as future anticancer agents. Nanoformulation techniques are suggested to be promising alternatives relative to the conventional drug delivery systems as they encompass exclusive drug delivery properties. It is concluded that nanonization can potentiate the beneficial effects of natural polyphenols against cancer by different mechanisms, hence opening a new field of research in oncology. However, it should be mentioned that all of the abovementioned formulations were evaluated in cellular and/or animal models of malignancies; thus, a long path lies ahead of commercializing these agents, including assessment of their safety and efficacy in healthy as well as cancerous subjects in preclinical and clinical settings.

\section{Author contributions}

All authors contributed toward data analysis, drafting and critically revising the paper and agree to be accountable for all aspects of the work.

\section{Disclosure}

The authors report no conflicts of interest in this work.

\section{References}

1. Ochwang'i DO, Kimwele CN, Oduma JA, Gathumbi PK, Mbaria JM, Kiama SG. Medicinal plants used in treatment and management of cancer in Kakamega County, Kenya. J Ethnopharmacol. 2014;151(3): 1040-1055.

2. Jemal A, Siegel R, Xu J, Ward E. Cancer statistics, 2010. CA Cancer J Clin. 2010;60(5):277-300.

3. Nagavarma B, Yadav HK, Ayaz A, Vasudha L, Shivakumar H. Different techniques for preparation of polymeric nanoparticles - a review. Asian $J$ Pharm Clin Res. 2012;5(3):16-23.

4. Hede S, Huilgol N. "Nano": the new nemesis of cancer. $J$ Cancer Res Ther. 2006;2(4):186.

5. Wang X, Wang Y, Chen ZG, Shin DM. Advances of cancer therapy by nanotechnology. Cancer Res Treat. 2009;41(1):1-11.
6. Brandl M. Liposomes as drug carriers: a technological approach. Biotechnol Annu Rev. 2001;7:59-85.

7. Matsumura Y, Hamaguchi T, Ura T, et al. Phase I clinical trial and pharmacokinetic evaluation of NK911, a micelle-encapsulated doxorubicin. Br J Cancer. 2004;91(10):1775-1781.

8. Mallick S, Choi JS. Liposomes: versatile and biocompatible nanovesicles for efficient biomolecules delivery. J Nanosci Nanotechnol. 2014; 14(1):755-765.

9. Zhang L, Gu F, Chan J, Wang A, Langer R, Farokhzad O. Nanoparticles in medicine: therapeutic applications and developments. Clin Pharmacol Ther. 2008;83(5):761-769.

10. Rasouli H, Farzaei MH, Mansouri K, Mohammadzadeh S, Khodarahmi R. Plant cell cancer: may natural phenolic compounds prevent onset and development of plant cell malignancy? A literature review. Molecules. 2016;21(9):1104.

11. Hosein Farzaei M, Bahramsoltani R, Rahimi R. Phytochemicals as adjunctive with conventional anticancer therapies. Curr Pharm Des. 2016; 22(27):4201-4218.

12. Danhier F, Ansorena E, Silva JM, Coco R, Le Breton A, Préat V. PLGA-based nanoparticles: an overview of biomedical applications. J Control Release. 2012;161(2):505-522.

13. Beck-Broichsitter M, Rytting E, Lebhardt T, Wang X, Kissel T. Preparation of nanoparticles by solvent displacement for drug delivery: a shift in the "ouzo region" upon drug loading. Eur J Pharm Sci. 2010;41(2): 244-253.

14. Reis CP, Neufeld RJ, Ribeiro AJ, Veiga F. Nanoencapsulation I. Methods for preparation of drug-loaded polymeric nanoparticles. Nanomedicine. 2006;2(1):8-21.

15. Kumari A, Yadav SK, Yadav SC. Biodegradable polymeric nanoparticles based drug delivery systems. Colloids SurfB Biointerfaces. 2010; 75(1):1-18.

16. Tahmasebi Birgani M, Erfani-Moghadam V, Babaei E, et al. Dendrosomal nano-curcumin; the novel formulation to improve the anticancer properties of curcumin. Prog Biol Sci. 2015;5(2):143-158.

17. Paleos CM, Tsiourvas D, Sideratou Z, Pantos A. Formation of artificial multicompartment vesosome and dendrosome as prospected drug and gene delivery carriers. J Control Release. 2013;170(1):141-152.

18. Mohanty C, Acharya S, Mohanty AK, Dilnawaz F, Sahoo SK. Curcuminencapsulated MePEG/PCL diblock copolymeric micelles: a novel controlled delivery vehicle for cancer therapy. Nanomedicine. 2010; 5(3):433-449.

19. Prabaharan M, Grailer JJ, Steeber DA, Gong S. Stimuli-responsive chitosan-graft-poly(N-vinylcaprolactam) as a promising material for controlled hydrophobic drug delivery. Macromol Biosci. 2008;8(9):843-851.

20. Loftsson T, Masson M, Brewster ME. Self-association of cyclodextrins and cyclodextrin complexes. J Pharm Sci. 2004;93(5):1091-1099.

21. Chen L, Berry RM, Tam KC. Synthesis of $\beta$-Cyclodextrin-modified cellulose nanocrystals (CNCs)@ Fe3O4@ $\mathrm{SiO} 2$ superparamagnetic nanorods. ACS Sustain Chem Eng. 2014;2(4):951-958.

22. Hemraz UD, Campbell KA, Burdick JS, Ckless K, Boluk Y, Sunasee R. Cationic poly(2-aminoethylmethacrylate) and poly(N-(2-aminoethylmethacrylamide) modified cellulose nanocrystals: synthesis, characterization, and cytotoxicity. Biomacromolecules. 2014;16(1):319-325. 
23. Phan QT, Le MH, Le TTH, Tran THH, Xuan PN, Ha PT. Characteristics and cytotoxicity of folate-modified curcumin-loaded PLA-PEG micellar nano systems with various PLA: PEG ratios. Int J Pharm. 2016; 507(1):32-40.

24. Sinha V, Bansal K, Kaushik R, Kumria R, Trehan A. Poly- $\varepsilon$-caprolactone microspheres and nanospheres: an overview. Int J Pharm. 2004;278(1): $1-23$.

25. Casadio F, Leona M, Lombardi JR, Van Duyne R. Identification of organic colorants in fibers, paints, and glazes by surface enhanced Raman spectroscopy. Acc Chem Res. 2010;43(6):782-791.

26. Chouhan R, Bajpai A. Real time in vitro studies of doxorubicin release from PHEMA nanoparticles. J Nanobiotechnology. 2009;7(1):1.

27. Doktorovova S, Gokce E, Ozyazici M, Souto E. Lipid matrix nanoparticles: pharmacokinetics and biopharmaceutics. Curr Nanosci. 2009; 5(3):358-371.

28. Mehnert W, Mäder K. Solid lipid nanoparticles: production, characterization and applications. Adv Drug Deliv Rev. 2001;47(2):165-196.

29. Belting M, Sandgren S, Wittrup A. Nuclear delivery of macromolecules: barriers and carriers. Adv Drug Deliv Rev. 2005;57(4):505-527.

30. Bairagi SH, Salaskar PP, Loke SD, Surve NN, Tandel DV, Dusara MD. Medicinal significance of coumarins. Int JPharm Res. 2012; 4(2):16-19.

31. Beyth R, Milligan P, Gage B. Risk factors for bleeding in patients taking coumarins. Curr Hematol Rep. 2002;1(1):41-49.

32. Leal L, Ferreira A, Bezerra G, Matos F, Viana G. Antinociceptive, antiinflammatory and bronchodilator activities of Brazilian medicinal plants containing coumarin: a comparative study. J Ethnopharmacol. 2000; 70(2):151-159.

33. Castilho RO, Kaplan MAC. Chemosystematics of the rosiflorae. Braz J Biol. 2008;68(3):633-640.

34. Bhattacharyya SS, Paul S, De A, et al. Poly(lactide-co-glycolide) acid nanoencapsulation of a synthetic coumarin: cytotoxicity and biodistribution in mice, in cancer cell line and interaction with calf thymus DNA as target. Toxicol Appl Pharmacol. 2011;253(3):270-281.

35. Aas Z, Babaei E, Feizi MAH, Dehghan G. Anti-proliferative and apoptotic effects of dendrosomal farnesiferol c on gastric cancer cells. Asian Pac J Cancer Prev. 2015;16(13):5325-5329.

36. Panahi Y, Badeli R, Karami GR, Sahebkar A. Investigation of the efficacy of adjunctive therapy with bioavailability-boosted curcuminoids in major depressive disorder. Phytother Res. 2015;29(1):17-21.

37. Zaman MS, Chauhan N, Yallapu MM, et al. Curcumin nanoformulation for cervical cancer treatment. Sci Rep. 2016;6:20051.

38. Wu G, Huang H, Garcia Abreu J, He X. Inhibition of GSK3 phosphorylation of beta-catenin via phosphorylated PPPSPXS motifs of Wnt coreceptor LRP6. PLoS One. 2009;4(1):e4926.

39. Rushworth SA. Targeting the oncogenic role of miRNA in human cancer using naturally occurring compounds. Br J Pharmacol. 2011;162(2): 346-348.

40. Zhang B, Pan X, Cobb GP, Anderson TA. microRNAs as oncogenes and tumor suppressors. Dev Biol. 2007;302(1):1-12.

41. Xie M, Fan D, Zhao Z, et al. Nano-curcumin prepared via supercritical: improved anti-bacterial, anti-oxidant and anti-cancer efficacy. Int J Pharm. 2015;496(2):732-740.

42. Yallapu MM, Gupta BK, Jaggi M, Chauhan SC. Fabrication of curcumin encapsulated PLGA nanoparticles for improved therapeutic effects in metastatic cancer cells. J Colloid Interface Sci. 2010;351(1):19-29.

43. Yallapu MM, Maher DM, Sundram V, Bell MC, Jaggi M, Chauhan SC. Curcumin induces chemo/radio-sensitization in ovarian cancer cells and curcumin nanoparticles inhibit ovarian cancer cell growth. J Ovarian Res. 2010;3(1):1.

44. Punfa W, Yodkeeree S, Pitchakarn P, Ampasavate C, Limtrakul P. Enhancement of cellular uptake and cytotoxicity of curcumin-loaded PLGA nanoparticles by conjugation with anti-P-glycoprotein in drug resistance cancer cells. Acta Pharmacol Sin. 2012;33(6):823-831.

45. Yu Y, Zhang X, Qiu L. The anti-tumor efficacy of curcumin when delivered by size/charge-changing multistage polymeric micelles based on amphiphilic poly( $\beta$-amino ester) derivates. Biomaterials. 2014;35(10): 3467-3479.
46. Rejinold NS, Sreerekha P, Chennazhi K, Nair S, Jayakumar R. Biocompatible, biodegradable and thermo-sensitive chitosan-g-poly(Nisopropylacrylamide) nanocarrier for curcumin drug delivery. Int $J$ Biol Macromol. 2011;49(2):161-172.

47. Ntoutoume GMN, Granet R, Mbakidi JP, et al. Development of curcumincyclodextrin/cellulose nanocrystals complexes: new anticancer drug delivery systems. Bioorg Med Chem Lett. 2016;26(3):941-945.

48. Shiri S, Alizadeh AM, Baradaran B, et al. Dendrosomal curcumin suppresses metastatic breast cancer in mice by changing $\mathrm{m} 1 / \mathrm{m} 2$ macrophage balance in the tumor microenvironment. Asian Pac J Cancer Prev. 2015;16(9):3917-3922.

49. Ji G, Yang J, Chen J. Preparation of novel curcumin-loaded multifunctional nanodroplets for combining ultrasonic development and targeted chemotherapy. Int J Pharm. 2014;466(1):314-320.

50. Milano F, Mari L, van de Luijtgaarden W, Parikh K, Calpe S, Krishnadath KK. Nano-curcumin inhibits proliferation of esophageal adenocarcinoma cells and enhances the $\mathrm{T}$ cell mediated immune response. Front Oncol. 2013;3:137:1-11.

51. Adahoun MA, Al-Akhras MH, Jaafar MS, Bououdina M. Enhanced anti-cancer and antimicrobial activities of curcumin nanoparticles. Artif Cells Nanomed Biotechnol. 2017;45(1):98-107.

52. Bondì M, Craparo E, Picone P, et al. Curcumin entrapped into lipid nanosystems inhibits neuroblastoma cancer cell growth and activates Hsp70 protein. Curr Nanosci. 2010;6(5):439-445.

53. Mancarella S, Greco V, Baldassarre F, Vergara D, Maffia M, Leporatti S. Polymer-coated magnetic nanoparticles for curcumin delivery to cancer cells. Macromol Biosci. 2015;15(10):1365-1374.

54. Yan J, Wang Y, Zhang X, Liu S, Tian C, Wang H. Targeted nanomedicine for prostate cancer therapy: docetaxel and curcumin co-encapsulated lipid-polymer hybrid nanoparticles for the enhanced anti-tumor activity in vitro and in vivo. Drug Deliv. 2016;23(5):1757-1762.

55. Ochi MM, Amoabediny G, Rezayat SM, Akbarzadeh A, Ebrahimi B. In vitro co-delivery evaluation of novel pegylated nano-liposomal herbal drugs of silibinin and glycyrrhizic acid (Nano-phytosome) to hepatocellular carcinoma cells. Cell J. 2016;18(2):135-148.

56. Yamazaki K, Iwashina T, Kitajima J, Gamou Y, Yoshida A, Tannowa T. External and internal flavonoids from Madagascarian Uncarina species (Pedaliaceae). Biochem Syst Ecol. 2007;35(11):743-749.

57. Touré A, Xueming X. Flaxseed lignans: source, biosynthesis, metabolism, antioxidant activity, bio-active components, and health benefits. Compr Rev Food Sci Food Saf. 2010;9(3):261-269.

58. Adlercreutz H. Lignans and human health. Crit Rev Clin Lab Sci. 2007; 44(5-6):483-525.

59. Kalman DS, Feldman S, Feldman R, Schwartz HI, Krieger DR, Garrison R. Effect of a proprietary Magnolia and Phellodendron extract on stress levels in healthy women: a pilot, double-blind, placebocontrolled clinical trial. Nutr J. 2008;7(1):1.

60. Qiu N, Cai LL, Xie D, et al. Synthesis, structural and in vitro studies of well-dispersed monomethoxy-poly(ethylene glycol)-honokiol conjugate micelles. Biomed Mater. 2010;5(6):065006.

61. Akgun I, Erkucuk A, Pilavtepe M, Yesil-Celiktas O. Optimization of total alkannin yields of Alkanna tinctoria by using sub-and supercritical carbon dioxide extraction. $J$ Supercrit Fluids. 2011;57(1):31-37.

62. Sharma RS, Mishra V, Singh R, Seth N, Babu C. Antifungal activity of some Himalayan medicinal plants and cultivated ornamental species. Fitoterapia. 2008;79(7):589-591.

63. Lucena GM, Matheus FC, Ferreira VM, et al. Effects of ethanolic extract and naphthoquinones obtained from the bulbs of cipura paludosa on short-term and long-term memory: involvement of adenosine A1 and A2A receptors. Basic Clin Pharmacol Toxicol. 2013;112(4): 229-235.

64. Xu T-P, Shen H, Liu L-X, Shu Y-Q. Plumbagin from Plumbago Zeylanica $\mathrm{L}$ induces apoptosis in human non-small cell lung cancer cell lines through NF-אB inactivation. Asian Pac J Cancer Prev. 2013;14(4): $2325-2331$.

65. Israelsen WJ, Vander Heiden MG. Pyruvate kinase: function, regulation and role in cancer. Paper presented at: Seminars in Cell \& Developmental Biology; 2015. 
66. Duraipandy N, Lakra R, Kunnavakkam Vinjimur S, Samanta D, Sai P, Kiran MS. Caging of plumbagin on silver nanoparticles imparts selectivity and sensitivity to plumbagin for targeted cancer cell apoptosis. Metallomics. 2014;6(11):2025-2033.

67. Rivière C, Pawlus AD, Mérillon J-M. Natural stilbenoids: distribution in the plant kingdom and chemotaxonomic interest in Vitaceae. Nat Prod Rep. 2012;29(11):1317-1333.

68. Sanna V, Siddiqui IA, Sechi M, Mukhtar H. Resveratrol-loaded nanoparticles based on poly(epsiloncaprolactone) and poly(D,L-lactic-coglycolic acid)-poly(ethylene glycol) blend for prostate cancer treatment. Mol Pharm. 2013;10(10):3871-3881.

69. Carletto B, Berton J, Ferreira TN, et al. Resveratrol-loaded nanocapsules inhibit murine melanoma tumor growth. Colloids Surf B Biointerfaces. 2016;144:65-72.

70. Shao J, Li X, Lu X, et al. Enhanced growth inhibition effect of resveratrol incorporated into biodegradable nanoparticles against glioma cells is mediated by the induction of intracellular reactive oxygen species levels. Colloids Surf B Biointerfaces. 2009;72(1):40-47.

71. Guo L, Peng Y, Li Y, et al. Cell death pathway induced by resveratrolbovine serum albumin nanoparticles in a human ovarian cell line. Oncol Lett. 2015;9(3):1359-1363.

72. Mohan A, Narayanan S, Sethuraman S, Krishnan UM. Novel resveratrol and 5-fluorouracil coencapsulated in PEGylated nanoliposomes improve chemotherapeutic efficacy of combination against head and neck squamous cell carcinoma. Biomed Res Int. 2014;2014:424239.

73. Williams CA, Grayer RJ. Anthocyanins and other flavonoids. Nat Prod Rep. 2004;21(4):539-573.

74. Parhiz H, Roohbakhsh A, Soltani F, Rezaee R, Iranshahi M. Antioxidant and anti-inflammatory properties of the citrus flavonoids hesperidin and hesperetin: an updated review of their molecular mechanisms and experimental models. Phytother Res. 2015;29(3):323-331.

75. Leyva-López N, Gutierrez-Grijalva EP, Ambriz-Perez DL, Heredia JB. Flavonoids as cytokine modulators: a possible therapy for inflammationrelated diseases. Int J Mol Sci. 2016;17(6):921.

76. Peluso I, Miglio C, Morabito G, Ioannone F, Serafini M. Flavonoids and immune function in human: a systematic review. Crit Rev Food Sci Nutr. 2015;55(3):383-395

77. Sak K. Cytotoxicity of dietary flavonoids on different human cancer types. Pharmacogn Rev. 2014;8(16):122.

78. Ayoub M, de Camargo AC, Shahidi F. Antioxidants and bioactivities of free, esterified and insoluble-bound phenolics from berry seed meals. Food Chem. 2016;197:221-232.

79. Serafini M, Bugianesi R, Maiani G, Valtuena S, De Santis S, Crozier A. Plasma antioxidants from chocolate. Nature. 2003; (6952):1013.

80. Le Marchand L. Cancer preventive effects of flavonoids - a review. Biomed Pharmacother. 2002;56(6):296-301.

81. Xie Y, Song X, Sun X, et al. Identification of baicalein as a ferroptosis inhibitor by natural product library screening. Biochem Biophys Res Commun. 2016;473(4):775-780.

82. Liu A, Wang W, Fang H, et al. Baicalein protects against polymicrobial sepsis-induced liver injury via inhibition of inflammation and apoptosis in mice. Eur J Pharmacol. 2015;748:45-53.

83. Anandhi R, Annadurai T, Anitha TS, et al. Antihypercholesterolemic and antioxidative effects of an extract of the oyster mushroom, Pleurotus ostreatus, and its major constituent, chrysin, in Triton WR-1339-induced hypercholesterolemic rats. J Physiol Biochem. 2013;69(2):313-323.

84. Rashid S, Nafees S, Vafa A, et al. Inhibition of precancerous lesions development in kidneys by chrysin via regulating hyperproliferation, inflammation and apoptosis at pre clinical stage. Arch Biochem Biophys. 2016;606:1-9.

85. Li X, Huang J-M, Wang J-N, Xiong X-K, Yang X-F, Zou F. Combination of chrysin and cisplatin promotes the apoptosis of Hep G2 cells by up-regulating p53. Chem Biol Interact. 2015;232:12-20.

86. Shin YS, Kang SU, Park JK, et al. Anti-cancer effect of (-)epigallocatechin-3-gallate (EGCG) in head and neck cancer through repression of transactivation and enhanced degradation of $\beta$-catenin. Phytomedicine. 2016;23(12):1344-1355.
87. Shafiei SS, Solati-Hashjin M, Samadikuchaksaraei A, Kalantarinejad R, Asadi-Eydivand M, Abu Osman NA. Epigallocatechin gallate/layered double hydroxide nanohybrids: preparation, characterization, and in vitro anti-tumor study. PLoS One. 2015;10(8):e0136530.

88. Siddiqui IA, Bharali DJ, Nihal M, et al. Excellent anti-proliferative and pro-apoptotic effects of (-)-epigallocatechin-3-gallate encapsulated in chitosan nanoparticles on human melanoma cell growth both in vitro and in vivo. Nanomedicine. 2014;10(8):1619-1626.

89. Narayanan S, Mony U, Vijaykumar DK, Koyakutty M, Paul-Prasanth B, Menon D. Sequential release of epigallocatechin gallate and paclitaxel from PLGA-casein core/shell nanoparticles sensitizes drug-resistant breast cancer cells. Nanomedicine. 2015;11(6):1399-1406.

90. Abdolahad M, Janmaleki M, Mohajerzadeh S, Akhavan O, Abbasi S Polyphenols attached graphene nanosheets for high efficiency NIR mediated photodestruction of cancer cells. Mater Sci Eng C Mater Biol Appl. 2013;33(3):1498-1505.

91. Meng G, Chai K, Li X, Zhu Y, Huang W. Luteolin exerts pro-apoptotic effect and anti-migration effects on A549 lung adenocarcinoma cells through the activation of MEK/ERK signaling pathway. Chem Biol Interact. 2016;257:26-34.

92. Sabzichi M, Hamishehkar H, Ramezani F, et al. Luteolin-loaded phytosomes sensitize human breast carcinoma MDA-MB 231 cells to doxorubicin by suppressing Nrf2 mediated signalling. Asian Pac J Cancer Prev. 2014;15(13):5311-5316.

93. Majumdar D, Jung $\mathrm{KH}$, Zhang $\mathrm{H}$, et al. Luteolin nanoparticle in chemoprevention: in vitro and in vivo anticancer activity. Cancer Prev Res (Phila). 2014;7(1):65-73.

94. Murakami A, Ashida H, Terao J. Multitargeted cancer prevention by quercetin. Cancer Lett. 2008;269(2):315-325.

95. Minaei A, Sabzichi M, Ramezani F, Hamishehkar H, Samadi N. Co-delivery with nano-quercetin enhances doxorubicin-mediated cytotoxicity against MCF-7 cells. Mol Biol Rep. 2016;43(2):99-105.

96. Rezaei-Sadabady R, Eidi A, Zarghami N, Barzegar A. Intracellular ROS protection efficiency and free radical-scavenging activity of quercetin and quercetin-encapsulated liposomes. ArtifCells Nanomed Biotechnol. 2016;44(1):128-134.

97. Jafari S, Saeidnia S, Abdollahi M. Role of natural phenolic compounds in cancer chemoprevention via regulation of the cell cycle. Curr Pharm Biotechnol. 2014;15(4):409-421.

98. Saeidnia S, Abdollahi M. Antioxidants: friends or foe in prevention or treatment of cancer: the debate of the century. Toxicol Appl Pharmacol. 2013;271(1):49-63.

99. Mostafalou S, Mohammadi H, Ramazani A, Abdollahi M. Different biokinetics of nanomedicines linking to their toxicity: an overview. Daru. 2013;21(1):1.

100. Koopaei NN, Abdollahi M. Opportunities and obstacles to the development of nanopharmaceuticals for human use. Daru. 2016;24(1):23.

101. Pourmand A, Abdollahi M. Current opinion on nanotoxicology. Daru. 2012;20(1):1.

102. Donnenberg VS, Donnenberg AD. Multiple drug resistance in cancer revisited: the cancer stem cell hypothesis. J Clin Pharmacol. 2005;45(8):872-877.

103. Liang X-J, Chen C, Zhao Y, Wang PC. Circumventing tumor resistance to chemotherapy by nanotechnology. Methods Mol Biol. 2010 596:467-488.

104. Gupta S, Afaq F, Mukhtar H. Involvement of nuclear factor-kappa B, Bax and Bcl-2 in induction of cell cycle arrest and apoptosis by apigenin in human prostate carcinoma cells. Oncogene. 2002;21(23):3727-3738.

105. Emi M, Kim R, Tanabe K, Uchida Y, Toge T. Targeted therapy against Bcl-2-related proteins in breast cancer cells. Breast Cancer Res. 2005;7(6):1.

106. Fang X-B, Zhang J-M, Xie X, et al. pH-sensitive micelles based on acid-labile pluronic F68-curcumin conjugates for improved tumor intracellular drug delivery. Int J Pharm. 2016;502(1-2):28-37.

107. Raveendran R, Bhuvaneshwar GS, Sharma CP. Hemocompatible curcumin-dextran micelles as $\mathrm{pH}$ sensitive pro-drugs for enhanced therapeutic efficacy in cancer cells. Carbohydr Polym. 2016; $137: 497-507$ 
108. Ghosh D, Choudhury ST, Ghosh S, et al. Nanocapsulated curcumin: oral chemopreventive formulation against diethylnitrosamine induced hepatocellular carcinoma in rat. Chem Biol Interact. 2012;195(3): 206-214.

109. Kumar SSD, Surianarayanan M, Vijayaraghavan R, Mandal AB, Macfarlane DR. Curcumin loaded poly(2-hydroxyethyl methacrylate) nanoparticles from gelled ionic liquid - in vitro cytotoxicity and anticancer activity in SKOV-3 cells. Eur J Pharm Sci. 2014;51(1):34-44.
110. Milano F, Mari L, van de Luijtgaarden W, Parikh K, Calpe S, Krishnadath KK. Nano-curcumin inhibits proliferation of esophageal adenocarcinoma cells and enhances the $\mathrm{T}$ cell mediated immune response. Front Oncol. 2013;3:137.

\section{Publish your work in this journal}

The International Journal of Nanomedicine is an international, peerreviewed journal focusing on the application of nanotechnology in diagnostics, therapeutics, and drug delivery systems throughout the biomedical field. This journal is indexed on PubMed Central, MedLine, CAS, SciSearch ${ }^{\circledR}$, Current Contents ${ }^{\circledR} /$ Clinical Medicine,
Journal Citation Reports/Science Edition, EMBase, Scopus and the Elsevier Bibliographic databases. The manuscript management system is completely online and includes a very quick and fair peer-review system, which is all easy to use. Visit http://www.dovepress.com/ testimonials.php to read real quotes from published authors. 